\title{
Relationship of Pink Pigmentation in Rose Petals and Botrytis cinerea
}

\author{
Melissa Muñoz, ${ }^{1}$ James E. Faust, ${ }^{1}$ William C. Bridges, ${ }^{2}$ and Guido Schnabel ${ }^{1,+}$ \\ ${ }^{1}$ Department of Plant and Environmental Sciences, Clemson University, Clemson, SC 29634 \\ ${ }^{2}$ School of Mathematical and Statistical Sciences, Clemson University, Clemson, SC 29634
}

Accepted for publication 3 April 2020.

\begin{abstract}
Pink pigmentation on rose (Rosa $\times$ hybrida) petals in the form of round spots or irregular-shaped discoloration has been associated with Botrytis cinerea infection, but scientific evidence has been lacking to support this hypothesis. The unfounded association between pink pigmentation and Botrytis blight has been sufficient to warrant rejection of international shipments during inspection at the ports of entry. The objective of this research was to evaluate the relationship between pink pigmentation symptoms on rose petals and $B$. cinerea infection. Four shipments of 'Vendela' and 'Brighton' roses were received from a commercial grower. Intact rose flowers and detached petals were assessed separately, and symptom development and Botrytis blight incidence were evaluated. In addition, tissue pieces with and

wi

without pink pigmentation were placed in culture media to determine the frequency of $B$. cinerea isolation. Results showed that Botrytis blight incidence in whole flowers and petals of cut roses with and without pink pigmentations was not significantly different. $B$. cinerea was not isolated more frequently from pink-pigmented tissue compared with tissues lacking pink pigmentation. These results show that pink pigmentation in the form of round spots or irregular-shaped discoloration along the petal margins is not associated with $B$. cinerea infections.

Keywords: Botrytis cinerea, Botrytis blight, rose, Rosa $\times$ hybrida, cut flowers, pigment
\end{abstract}

The world export value of cut flowers in 2018 was $\$ 9$ billion, and the import of cut flowers to the United States was $\$ 1.6$ billion, with Colombia and Ecuador supplying $81 \%$ of the U.S. market (International Trade Centre 2019). The crop area under protected cultivation in Colombia and Ecuador is $\sim 8,500$ ha (Bendahmane et al. 2013). Botrytis cinerea Pers. is a fungal pathogen that affects cut rose production crops around the world (Blom and Tsujita 2003; Muñoz et al. 2019). B. cinerea infection can occur in rose flowers and leaves, resulting in Botrytis blight symptoms, or in the stems, leading to cane canker symptoms (Horst and Cloyd 2007). However, the most significant commercial losses occur when the fungus infects the flowers, which may lead to the development of necrotic petals, receptacle, and sepals. Botrytis blight symptoms typically appear in the postharvest environment; therefore, B. cinerea infection often remains symptomless until proper environmental conditions occur (Elad 1988). Typical B. cinerea infection symptoms in petals initially appear as necrotic or discolored spots that enlarge and sporulate under favorable conditions such as high relative humidity (>94\%) and temperatures between 15 and $25^{\circ} \mathrm{C}$ (Williamson et al. 1995). Initial symptoms can be confused with

${ }^{\dagger}$ Corresponding author: G. Schnabel; schnabe@clemson.edu

Technical Contribution No. 6853 of the Clemson University Experiment Station.

Funding: This work was funded by the American Floral Endowment. This material is based upon work supported by NIFA/USDA, under project number SC-1700501.

The author(s) declare no conflict of interest.

(C) 2020 The American Phytopathological Society other pathogenic infections including Alternaria alternata, Cladosporium cladosporioides, Epicoccum nigrum, and Penicillium citrinum (Muñoz et al. 2019).

The development of pink pigmentation on rose petals of white, yellow, and pink-petaled roses has been associated with $B$. cinerea infection (Missouri Botanical Garden n.d.; University of Minnesota Extension n.d.). The pink pigmentations can appear as small, round spots on any portion of the flower petal or in an irregular-shaped pattern along the margin of the flower petal (Fig. 1). The pink pigmentations appear in the greenhouses during flower development; however, the pink pigmentations are more often observed as the flowers get closer to the harvest point. International shipments are often rejected during inspection at the U.S. port of entry when pink pigmentation is observed, and only one small spot identified on one petal can cause the entire box of roses to be rejected. The relationship between pink pigmentation and $B$. cinerea infection has not been substantiated; therefore, the objective of this study was to evaluate the relationship between pink pigmentation presence and Botrytis blight incidence caused by $B$. cinerea infection in rose petals. To accomplish this, three experiments were performed using four shipments over time of the cut rose cultivars 'Brighton' and 'Vendela' at commercial harvest stage that were received from Colombia, South America, and processed at Clemson University, U.S.A.

\section{Experiment 1: Assessment of Botrytis Blight in Intact Flowers with and Without Pink Pigmentation}

Forty-eight roses were received per cultivar and shipment,onehalf of which were pigmented flowers (PF), and the other half were nonpigmented flowers (NPF) (Fig. 1). PF and NPF came from the 
same farm and greenhouses, and they were grown under the same management program. Six NPF and six PF were arbitrarily selected per cultivar from each of the four shipments (Table 1). Intact flowers were surface sterilized by dipping the flowers for $1 \mathrm{~min}$ in a sodium hypochlorite solution $(0.525 \%)$ followed by $1 \mathrm{~min}$ in sterile deionized water. Flowers were then allowed to dry for $5 \mathrm{~min}$ in a laminar flow hood. Self-adhesive labels (DEMCO Madison, WI) were used to identify pigmented petals (PP) throughout the experiment (Fig. 1A). The NPF and PF were placed in a humid chamber (100\% relative humidity) and

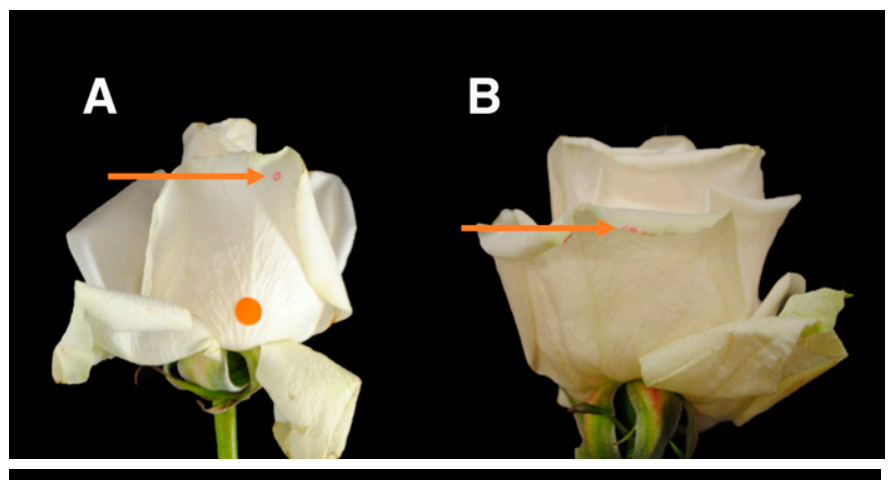

\section{FIGURE 1}

Examples of pink pigmentations observed in the petals of cut rose flowers. Arrows pointing to $\mathbf{A}$, pink pigmentation displayed as a spot, and $\mathbf{B}$, pink pigmentation located along the irregular-shaped margin of the petal. incubated for 7 days, at which time Botrytis blight incidence and severity were evaluated.

The data set for the assessment of Botrytis blight in intact flowers was a $2 \times 4 \times 2$ factorial model containing two cultivars, four shipments, and two pigmentation presence possibilities (NPF and $\mathrm{PF})$. The hypothesis tested was that flowers with pink pigmentation presence have a higher Botrytis blight incidence and severity than flowers without pink pigmentation. An ANOVA test ( $P$ value 0.05$)$ was used to evaluate the relationship between Botrytis blight and presence of pigmentation, shipment, cultivar, and their interactions. Data analysis was performed using JMP Pro version 13.2.0 (SAS Institute, Cary, NC). No statistical differences were observed between NPF and PF for Botrytis blight incidence or severity either in Brighton or Vendela flowers (Table 2). Additionally, when Botrytis blight occurred in the PF treatment, it started at petal locations other than the pink-pigmented areas on $91.2 \%$ of the flowers.

No differences were observed in this experiment for the disease incidence or severity between cultivars. A shipment effect was observed for both disease incidence and severity (Table 3). For example, disease incidence ranged from 42 to $100 \%$ of the flowers received per shipment.

\section{Experiment 2: Assessment of Botrytis Blight in Detached Petals with and Without Pink Pigmentation}

Six NPF and PF were arbitrarily selected per cultivar from each of the four shipments. From each NPF, three nonpigmented petals $\left(\mathrm{NPF}_{\mathrm{NPP}}\right)$ were selected, and from each $\mathrm{PF}$, three nonpigmented petals $\left(\mathrm{PF}_{\mathrm{NPP}}\right)$ and three pigmented petals $\left(\mathrm{PF}_{\mathrm{PP}}\right)$ were selected (Table 1).

\begin{tabular}{|c|c|c|c|c|}
\hline \multirow[t]{3}{*}{ Various rose tissues } & \multirow[b]{3}{*}{ Abbreviation } & \multirow{2}{*}{\multicolumn{3}{|c|}{ Experiment }} \\
\hline & & & & \\
\hline & & 1: Intact flowers & 2: Detached petals & 3: Botrytis isolation \\
\hline Pigmented flowers & $\mathrm{PF}$ & $\checkmark$ & & \\
\hline Nonpigmented flowers & NPF & $\checkmark$ & & \\
\hline Pigmented petals from pigmented flowers & $\mathrm{PF}_{\mathrm{PP}}$ & & $\checkmark$ & \\
\hline Spot-shaped pigmented petals from pigmented flowers & & & & $\checkmark$ \\
\hline $\begin{array}{l}\text { Irregular-shaped, pigmented petals from pigmented } \\
\text { flowers }\end{array}$ & & & & $\checkmark$ \\
\hline
\end{tabular}

\begin{tabular}{|c|c|c|c|c|c|c|c|c|c|}
\hline \multirow[b]{3}{*}{ Cultivar } & ght a & rytis c & incide & $\begin{array}{l}\text { ues ob } \\
\text { evaluat }\end{array}$ & $\begin{array}{l}\text { 2 } 2 \\
\text { d in th } \\
\text { perime }\end{array}$ & cultiv & hton & ndela $f$ & three \\
\hline & \multicolumn{2}{|c|}{$\begin{array}{l}\text { Botrytis blight } \\
\text { incidence in intact } \\
\text { flowers }(\%)^{\mathrm{a}}\end{array}$} & \multicolumn{3}{|c|}{$\begin{array}{l}\text { Botrytis blight incidence in } \\
\text { detached petals }(\%)^{\mathbf{b}}\end{array}$} & \multicolumn{4}{|c|}{$\begin{array}{c}\text { Botrytis isolation attempts from pigmented spots and } \\
\text { edges }(\%)^{c}\end{array}$} \\
\hline & NPF & PF & $\mathrm{NPF}_{\mathrm{NPP}}$ & $\mathrm{PF}_{\mathrm{NPP}}$ & $\mathrm{PF}_{\mathrm{PP}}$ & $\mathrm{NPF}_{\mathrm{NPP}}$ & $\mathrm{PF}_{\mathrm{NPP}}$ & PF $F_{\text {Ppspot }}$ & $\mathrm{PF}_{\mathrm{PPmargin}}$ \\
\hline Brighton & 66.77 & 62.50 & 0.00 & 1.85 & 0.00 & 0.08 & 0.63 & 0.08 & 0.00 \\
\hline
\end{tabular}

${ }^{\text {a }}$ Pigmentation presence for the intact flower experiment included nonpigmented flowers (NPF) and pigmented flowers (PF).

${ }^{\mathrm{b}}$ Pigmentation presence for the detached petal experiment included NPF with nonpigmented petals $\left(\mathrm{NPF}_{\mathrm{NPP}}\right), \mathrm{PF}_{\text {with nonpigmented petals }}\left(\mathrm{PF} \mathrm{NPP}_{\mathrm{NP}}\right)$, and $\mathrm{PF}$ with pigmented petals $\left(\mathrm{PF}_{\mathrm{PP}}\right)$.

${ }^{\mathrm{c}}$ For the isolation experiments, the pigmentation presence was the same as for the petal experiment, but the $\mathrm{PF}_{\mathrm{PP}}$ was subdivided into pink spots $\left(\mathrm{PF}_{\mathrm{PPspot}}\right)$ and pink petal margins $\left(\mathrm{PF}_{\mathrm{PPmargin}}\right)$. 
Each petal was surface sterilized by immersion in a sodium hypochlorite solution as described in experiment 1 ; then, the three petals from each flower were placed in 15-cm-diameter Petri dishes with filter paper and $1 \mathrm{ml}$ of water. A high relative humidity (100\%) environment was maintained by placing the Petri dishes in clear, sealable, plastic bags (3.78 liters). The petals were incubated at $22^{\circ} \mathrm{C}$ for 7 days under 12-h light and 12-h dark intervals. Botrytis blight incidence and severity were evaluated on all individual petals. For $\mathrm{PF}_{\mathrm{PP}}$, the width of the pink-pigmented area at its largest point was measured before and after incubation to assess potential expansion of pink pigmentations.

The data set used for the assessment of Botrytis blight in the detached petals consisted of a $2 \times 4 \times 3$ factorial model, containing two cultivars, four shipments, and three pigmentation presence options $\left(\mathrm{NPF}_{\mathrm{NPP}}, \mathrm{PF}_{\mathrm{NPP}}\right.$, and $\left.\mathrm{PF}_{\mathrm{PP}}\right)$. An ANOVA test $(P$ value 0.05$)$ was used to evaluate the relationship between Botrytis blight incidence and the presence of pigmentation, shipment, and cultivar. Data analysis was performed using JMP Pro version 13.2.0 (SAS Institute).

No relationship was observed between pigmentation presence and Botrytis blight incidence (Table 3). When Botrytis blight occurred in the $\mathrm{PF}_{\mathrm{PP}}$ treatment, symptoms most often began in an area of the petal different than the pink pigmentation. For example, only two of the total 126 petals from the treatment $\mathrm{PF}_{\mathrm{PP}}$ exhibited Botrytis blight development starting over the pink pigmentation area, whereas the other petals showed no Botrytis blight or the disease symptoms developed in a portion of the petal other than the pink-pigmented area.

No relationship was observed between Botrytis blight and shipments for this experiment. The cultivar Vendela showed a significantly higher Botrytis blight incidence (10.9\%) compared with Brighton $(0.4 \%)$. The diameter of the round, pink pigmentations on the flower petals averaged $1.7 \mathrm{~mm}$, whereas the irregular pink pigmentation patterns observed along the flower petal margin averaged of $26.4 \mathrm{~mm}$ in length. Pink pigmentation areas did not enlarge or develop any additional symptoms during the experiment, suggesting that the pink pigmentations did not originate from bacterial or fungal infections.

\section{Meta-analysis Between Intact Flower and Detached Petal Assessment}

Forest plot meta-analysis was done to identify possible common effects from experiments 1 and 2. The null hypothesis was that Botrytis blight incidence between pigmented tissues (petals or flowers) and nonpigmented tissues was different. The confidence intervals for each differential comparison are indicated by the horizontal lines (Fig. 2), and the zero value on the $x$ axis identifies the null value; therefore, as the confidence interval crosses the null value (0), the hypothesis is rejected. Additionally, as the confidence intervals overlap between comparisons, then the response is the same. Thus, the results demonstrate no statistical difference between the incidence of Botrytis blight on pigmented or nonpigmented tissues (i.e., pink pigmentation is not indicative of Botrytis blight).

\section{Experiment 3: Assessment of Tissue Pieces with and Without Pigmentation for the Presence of $B$. cinerea}

Pink pigmentations were divided into two categories characterized as pink spots located in the middle of the petals or irregularshaped pink areas located along the margin of the petals. Thus, petals were categorized into four groups: $\mathrm{PF}_{\mathrm{PP}}$ with round pink spots, $\mathrm{PF}_{\mathrm{PP}}$ with irregular-shaped pink margins, $\mathrm{NPF}_{\mathrm{NPP}}$, and $\mathrm{PF}_{\mathrm{NPP}}$ (Table 1). Eight petals from each cultivar were selected for each of the four groups. Within each group, four petals were surface sterilized in sodium hypochlorite solution as described above, whereas the other four petals did not receive any sterilization. A $9-\mathrm{mm}^{2}$ area of petal tissue was removed from each petal directly from the pink-pigmented tissues if they were present $\left(\mathrm{PF}_{\mathrm{PP}}\right.$ in form of round spots or irregular-shaped margins), or from any portion of the petal if they did not have pink pigmentation $\left(\mathrm{NPF}_{\mathrm{NPP}}, \mathrm{PF}_{\mathrm{NPP}}\right) . B$. cinerea isolation attempts were performed by placing the tissue pieces into potato dextrose agar (PDA) medium (Difco, Detroit, MI) in 9-cm-diameter Petri dishes to determine if $B$. cinerea could be cultured directly from the tissue. Then, Petri dishes with the tissue pieces were incubated at $22^{\circ} \mathrm{C}$ and 12 -h light/dark intervals. After 10 days, Petri dishes were evaluated to determine incidence of $B$. cinerea and the appearance of other fungi or bacteria. Assessment of tissues for the presence or the absence of Botrytis blight and other microorganisms was conducted on the second, third, and fourth shipments. Statistical analysis using the $\chi^{2}$ test was performed to determine if the probability of obtaining a $B$. cinerea isolate in culture increased based on pigmentation presence, cultivar, and/or surface sterilization treatment.

No statistical differences were observed in the $B$. cinerea isolation for pigmentation presence, cultivar (Table 2), or surface sterilization treatment (Table 3 ). The success of $B$. cinerea isolation varied between shipments. Most cultured samples yielded no biotic activity; however, 15 different microorganisms were isolated from the tissue, including Diplodia sp., Alternaria sp., Botrytis sp., Epicoccum sp., Penicillium sp., Cladosporium sp., Fusarium sp.,

\begin{tabular}{|c|c|c|c|}
\hline \multicolumn{4}{|c|}{$\begin{array}{l}\text { TABLE } 3 \\
\text { ANOVA table for the three evaluated experiments using the rose cultivars Brighton and Vendela (significance: } P<0.05)\end{array}$} \\
\hline Source & $\begin{array}{l}\text { Botrytis blight incidence in intact } \\
\text { flowers } \mathrm{s}^{\mathrm{a}}\end{array}$ & $\begin{array}{l}\text { Botrytis blight incidence in detached } \\
\text { petals } \mathbf{s}^{\mathbf{b}}\end{array}$ & $\begin{array}{l}\text { Botrytis isolation attempts from pigmented } \\
\text { spots and edges }{ }^{c}\end{array}$ \\
\hline Pigmentation & 0.8987 & 0.3865 & 0.1071 \\
\hline Shipment & 0.000001 & 0.0803 & 0.0094 \\
\hline Cultivar & 0.2813 & 0.00001 & 0.7516 \\
\hline
\end{tabular}

\footnotetext{
${ }^{a}$ Pigmentation presence for the intact flower experiment included nonpigmented flowers (NPF) and pigmented flowers (PF).

${ }^{b}$ Pigmentation presence for the detached petal experiment included NPF with nonpigmented petals, PF with nonpigmented petals, and PF with pigmented petals $\left(\mathrm{PF}_{\mathrm{PP}}\right)$.

${ }^{\mathrm{c}}$ For the isolation experiments, the pigmentation presence was the same as for the petal experiment, but the $\mathrm{PF}_{\mathrm{PP}}$ was subdivided into pink spots and pink petal margins.

${ }^{d}$ The bleach treatment compared petals that received surface sterilization with sodium hypochlorite and petals that did not receive any surface sterilization.
} 
other unidentified fungi producing a brown colony in PDA, and different bacteria species. Koch's postulates were attempted using the most frequently isolated microorganisms during this experiment (Diplodia sp., Alternaria sp., Botrytis sp. Epicoccum sp., Penicillium sp., and Cladosporium sp.). However, reinfection of the petal tissue was not always possible, and when it was successful the pink pigmentations were never replicated as a symptom of infection for any of the microorganisms used in inoculation.

The $\chi^{2}$ analysis showed that the incidence for all the microorganisms isolated was affected by pigmentation presence, shipment, cultivar, and bleach treatment (Table 4). Culturable fungi and bacteria were more likely to occur in pigmented compared with nonpigmented petals. For example, 47.9 and $43.7 \%$ of the total tissue pieces collected from $\mathrm{PF}_{\mathrm{PP}}$ edges and $\mathrm{PF}_{\mathrm{PP}}$ spots and placed in PDA resulted in the isolation of a microorganism, whereas for $\mathrm{NPF}_{\mathrm{NPP}}$ and $\mathrm{PF}_{\mathrm{NPP}}$ the percentage of successful isolation of any microorganism was 25 and $14.9 \%$ respectably.

This could be a result of opportunistic microorganisms taking advantage of already damaged tissue. Weakened plant tissue, such as abnormally pigmented spots and edges, may facilitate penetration and colonization of these opportunistic fungi, which otherwise do not cause problems. Tissue without surface sterilization developed $39.6 \%$ more microorganism colonies compared with surface-sterilized tissue, suggesting that several of the isolated microorganisms were contaminants on the petal surface, not microorganisms growing inside the petal tissue. For example,

\section{TISSUE PIGMENTATION PRESENCE COMPARISON}

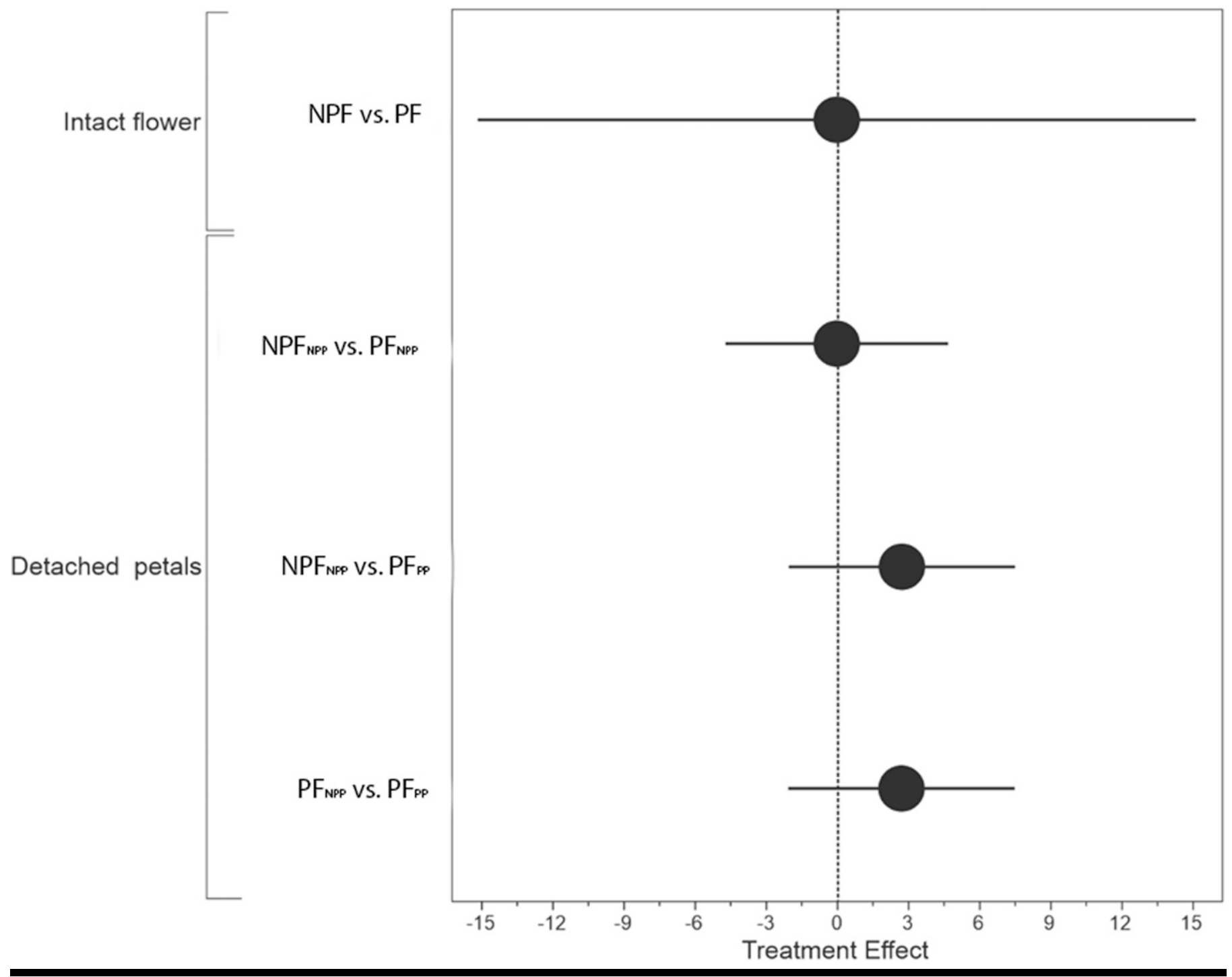

FIGURE 2

Forest plot analysis for comparison between pigmentation presence. Null value $=0$. Pairs of different pigmentation presence options that overlap at some point with the null value indicate no statistical difference between them. Pigmentation presence pairs that overlap each other at some point of the graph showed a common response among them. The uppermost tree plot compares nonpigmented flowers (NPF) and pigmented flowers (PF) in the intact flower experiments $(P=0.05)$. The lower three plots provide comparisons of the detached petal experiments $(P=0.05)$. The second tree plot compares nonpigmented petals from nonpigmented flowers ( $\mathrm{NPF}_{\mathrm{NPP}}$ ) and nonpigmented petals from pigmented flowers $\left(\mathrm{PF}_{\mathrm{NPP}}\right)$. The third tree plot compares $\mathrm{NPF}_{\mathrm{NPP}}$ and pigmented petals from pigmented flowers $\left(\mathrm{PF}_{\mathrm{PP}}\right)$. The fourth tree plot compares $\mathrm{PF}_{\mathrm{NPP}}$ and $\mathrm{PF}_{\mathrm{PP}}$. 


\section{TABLE 4}

$\chi^{2}$ values for frequency in the isolation of any culturable microorganism (significance: $P<\mathbf{0 . 0 5}$ )

Source Frequency of culturable microorganism

Shipment

0.0022

Cultivar $^{\mathrm{a}}$

0.0221

Presence of pigmentation ${ }^{\mathrm{b}}$

0.0018

Bleach treatment ${ }^{\mathrm{c}}$

0.00002

${ }^{\text {a }}$ Cultivar refers to comparison between Brighton and Vendela flower tissue.

${ }^{b}$ Presence of pigmentation include the following categories: nonpigmented flowers with nonpigmented petals, pigmented flowers (PF) with nonpigmented petals, and PF with pigmented petals subdivided as pink spots and pink petal margins.

c The bleach treatment compared petals that received surface sterilization with sodium hypochlorite and petals that did not receive any surface sterilization.

Cladosporium sp., Penicillium sp., and a couple of bacteria species were isolated exclusively from tissue without surface sterilization. Vendela displayed a higher frequency of microorganism growth than Brighton.

\section{Conclusions}

The pink pigmentations on rose petals in the form of spots and discolored edges are not a result of $B$. cinerea infections, and their presence does not result in an increased Botrytis blight incidence or severity. Pigmented tissue revealed a higher frequency of opportunistic fungi and bacteria, perhaps due to weakened tissue allowing for easier colonization. Most of the microorganisms isolated are not known to be economically important pathogens of rose.

The specific cause of pink pigmentation in the rose tissue remains unknown. Our current hypothesis is that pink pigmentation is a phytotoxic response to chemical applications, because these pink pigmentations appear more frequently during periods of high Botrytis blight pressure when the number and frequency of fungicide applications increase. Additional research needs to be conducted to determine the actual cause of pink pigmentation.

\section{Acknowledgments}

We thank Patricia Karen Bryson and Kelly Lewis for all the technical support, Paul Millar for helping with the data collection, and 'Flores de San Alejo S.A.S.' for helping to provide the plant material.

\section{Literature Cited}

Bendahmane, M., Dubois, A., Raymond, O., and Bris, M. L. 2013. Genetics and genomics of flower initiation and development in roses. J. Exp. Bot. 64: 847-857.

Blom, T. J., and Tsujita, M. J. 2003. Production and marketing: Cut rose production. Pages 594-600 in: Encyclopedia of Rose Science. A. V. Roberts, ed. Elsevier, Oxford, U.K.

Elad, Y. 1988. Latent infection of Botrytis cinerea in rose flowers and combined chemical physiological control of the disease. Crop Prot. 7:361-366.

Horst, R. K., and Cloyd, R. A. 2007. Pages 20-22 in: Compendium of Rose Diseases and Pests, 2nd Ed. American Phytopathological Society, St. Paul, MN.

International Trade Centre (ITC). 2019. http://www.trademap.org/Product_ SelCountry_TS.aspx?nvpm $=1 \% 7 \mathrm{c} 842 \% 7 \mathrm{c} \% 7 \mathrm{c} \% 7 \mathrm{c} \% 7 \mathrm{c} 0603 \% 7 \mathrm{c} \% 7 \mathrm{c} \%$ 7c4\%7c1\%7c1\%7c1\%7c2\%7c1\%7c1\%7c1\%7c1\&AspxAutoDetectCookieSupport=1 [Accessed March 18, 2020].

Missouri Botanical Garden. n.d. Botrytis blight. http://www. missouribotanicalgarden.org/gardens-gardening/your-garden/help-for-thehome-gardener/advice-tips-resources/pests-and-problems/diseases/fungalspots/botrytis-blight.aspx [Accessed April 6, 2019].

Muñoz, M. E., Faust, J., and Schnabel, G. 2019. Characterization of Botrytis cinerea from commercial cut flower roses. Plant Dis. 103:1577-1583.

University of Minnesota Extension. n.d. What's wrong with my plant? Garden: University of Minnesota Extension. https://apps.extension.umn.edu/garden/ diagnose/plant/annualperennial/roses/flowersspots.html [Accessed April 6, 2019].

Williamson, B., Duncan, G. H., Harrison, J. G., Harding, L. A., Elad, Y., and Zimand, G. 1995. Effect of humidity on infection of rose petals by dry-inoculated conidia of Botrytis cinerea. Mycol. Res. 99:13031310. 